\title{
politics today
}

Second edition

Scandinavian politics today

David Arter 


\section{Scandinavian politics today}

\section{MANCHESTER 1824}

Manchester University Press 


\section{Politics Today}

Series editor: Bill Jones

Ideology and politics in Britain today Ian Adams

Political ideology today, 2nd edition Ian Adams

Scandinavian politics today, 2nd edition David Arter

American society today Edward Ashbee

US politics today, 2nd edition Edward Ashbee

French politics today, new edition David S. Bell

Local government today, 3rd edition J. A. Chandler

Irish politics today, 4th edition Neil Collins and Terry Cradden

Political issues in Ireland today, 3rd edition Neil Collins and Terry Cradden (editors)

US elections today (Elections USA, 2nd edition) Philip John Davies

Political issues in America today Philip John Davies and Fredric A. Waldstein (editors)

Devolution in Britain today, 2nd edition Russell Deacon

Spanish politics today John Gibbons

The Politics Today companion to American government Alan Grant and Edward Ashbee

European politics today, 2nd edition Patricia Hogwood and Geoffrey K. Roberts

Dictionary of British politics Bill Jones

Political issues today, 5 th edition Bill Jones (editor)

British politics today, 7 th edition Bill Jones and Dennis Kavanagh

Political issues in the world today Don MacIver

Italian politics today Hilary Partridge

The Politics Today companion to the British Constitution Colin Pilkington

German politics today Geoffrey Roberts

The Politics Today companion to West European politics Geoffrey K. Roberts and

Patricia Hogwood

Debates in British politics today Lynton Robins and Bill Jones (editors)

Parliament today Michael Rush

Russian politics today Michael Waller

Britain in the European Union today, 3rd edition Duncan Watts and Colin Pilkington 


\section{Scandinavian politics today}

Second edition

David Arter

Manchester University Press

Manchester and New York

distributed in the United States exclusively by Palgrave Macmillan 
Copyright (C) David Arter 1999, 2008

The right of David Arter to be identified as the author of this work has been asserted by him in accordance with the Copyright, Designs and Patents Act 1988.

First edition published 1999 by Manchester University Press

This edition published 2008 by Manchester University Press

Oxford Road, Manchester M13 9NR, UK

and Room 400, 175 Fifth Avenue, New York, NY 10010, USA

Distributed in the United States exclusively by

Palgrave Macmillan, 175 Fifth Avenue, New York,

NY 10010, USA

Distributed in Canada exclusively by

UBC Press, University of British Columbia, 2029 West Mall,

Vancouver, BC, Canada V6T 1 Z2

British Library Cataloguing-in-Publication Data

A catalogue record for this book is available from the British Library

Library of Congress Cataloging-in-Publication Data applied for

ISBN 9780719078538 paperback

This edition first published 2008

17161514131211100908

1098766543321

Typeset by R. J. Footring Ltd, Derby

Printed in Great Britain

by Bell \& Bain Ltd, Glasgow 